\title{
TRANSLATION IN SEMANTICALLY-RESTRICTED AND PROFESSIONAL DOMAINS: IN SEARCH OF A THEORY - EDITORIAL TO RIL 18.
}

\author{
IWONA WITCZAK-PLISIECKA \\ University of Lodz \\ iwona.plisiecka@uni.lodz.pl \\ marina Platonova \\ Riga Technical University \\ marina.platonova@rtu.lv
}

\begin{abstract}
This paper comments on selected problems related to the theory and practice of translation in various professional, and other semantically-restricted domains. The text introduces a selection of papers published in Research in Language, Vol. 18, No. 3, which together with a number of papers published in RiL earlier issues collectively present various research programmes which link translation and specialised discourses.

The field of specialised languages is constantly growing, including new professional varieties and new approaches. There are numerous publications and journals focusing on LSP problems, as well as conferences which offer fora for relevant discussions. Selected articles in the volume originated from conference meetings "Meaning in Translation," held in Riga, Latvia. The present paper comments on selected approaches to semanticallyrestricted domains in translation and features of specialised and professional discourses.
\end{abstract}

Keywords: semantically-restricted domain; LSP; language for specific purpose; translation

\section{Introduction}

Translation in professional and semantically-restricted domains invites research in various theoretical and applied perspectives. There is a huge variety and significant dynamicity within specialised languages. The field is constantly growing discovering new subjects for analysis and new methodology. As a result, there are numerous publications, including handbooks focused on LSP problems (e.g. Paltridge \& Starfield 2013, Humbley, Budin \& Laurén 2018), book series (e.g. Routledge Research in 
English for Specific Purposes or Routledge Introductions to English for Specific Purposes, both edited by Brian Paltridge and Sue Starfield), and internet sites providing LSP guidance. There are also journals devoted solely to LSP problems, e.g. English for Specific Purposes (Elsevier), LSP JournalLanguage for special purposes, professional communication, knowledge management and cognition (Copenhagen, Denmark), Journal of Applied Linguistics and Professional Practice (Equinox Publishing), Ibérica (Universidad de Cadiz, Spain), as well as conferences which offer fora for relevant discussions, e.g. "Meaning in Translation" (e.g. 2020) in Riga, Latvia. There are also scientific journals devoted to specific subdomains of LSP, e.g.: Journal of English for Academic Purposes (Elsevier); Comparative Legilinguistics (Adam Mickiewicz University, Poznan, Poland), International Journal of Law, Language and Discourse (City University of Hong Kong), The Journal of Medical English Education (Japan), to name just a few.

Despite the common presence of LSP in the research space, the theoretical account of the phenomenon is far from complete, and much as it may be the case that no such account is possible in the ideal form, there are clearly aspects which invite immediate research. This text introduces a selection of papers published in Research in Language, Vol. 18, No. 3, which together with a number of papers published in RiL earlier issues (e.g. Faber \& Cabezas-Garcia 2019) collectively present various research programmes which link translation and specialised discourses.

\section{LSP - a definition}

The first question to ask is what an LSP is. The common acronym denotes "language for a specific purpose", or "language for a special purpose" (cf. Crystal 2018, p. 526; Gollin-Kies, Hall \& Moore 2015). Williams (2014, p. 1) reports that Google shows that "English for Specific Purposes" outnumbers "English for Special Purposes" by a ratio of roughly 14 to 1 (respectively 955,000 hits vs 66,200 hits). He further points to the fact that 'the preference for 'Specific' denotes an awareness that the type of language that ESP scholars are concerned with is not so much 'special' in itself as pertaining to 'specific' spheres of professional and institutional communication in English. ESP comes within the realm of 'specialized' (as opposed to 'special') discourse" (Williams 2014, p. 1).

A few decades ago LSP was mainly used to refer to discourses (written or spoken) in the domain of law, business, and medicine, but now embraces many more domains and the career that academic discourse has made over the last years is particularly impressive. However, legal language, medical language, and business language were seen as typical examples of LSPs, and this perspective has continued to the present day. Research on LSP originated in the context of English as an international language, a lingua franca of today's world, but the emergence 
of specialised varieties is universal across natural languages and LSPs can be discussed as subdomains in many other languages. In this text, the focus is on English as a foreign language, and consequently, English in translation, i.e. English vis-à-vis other natural languages.

LSP studies are commonly perceived as pedagogy-oriented (cf. Hutchinson \& Waters 1987). The classifications of languages for specific purposes can often serve to design curricula rather than inspire theoretical research, whether applied in a non-pedagogical sense or performed as art for art's sake (cf., e.g., Woodrow 2018, Day \& Krzanowski 2011). Even university departments emphasise the importance of providing their students with a link between education and the potential future workplace, placing emphasis on teaching practical (and pragmatic) skills.

Quite naturally, the origin of LSP research in the second part of the $20^{\text {th }} \mathrm{c}$. is paired with theoretical moves such as the appearance of Halliday's systemic functional grammar in the 1960s and interest in different registers and genres (cf. Bhatia 1983) in general as well as in EFL (English as a Foreign Language) and ELT (English Language Teaching) contexts.

It is sometimes indicated (e.g. Orr 2002) that LSPs are varieties largely unfamiliar not only to non-native, but also to native speakers, which would require special training also in the domestic education context. Another label used in such contexts is English for Occupational Purposes (EOP) (cf. Belcher 2004). Even though there are theory-oriented research programmes as well as accounts, most definitions of LSP emphasise that it denotes the knowledge, or the practiceoriented learning and teaching process focused on a variety of English to be used in a specific domain (e.g. Paltridge \& Starfield 2013; Johns 2013). Typically, such definitions emphasise that the process of teaching and learning an LSP is the process of building a special type of communicative competence, an ability to behave naturally in the professional context in question. For instance, Crystal (2018) cites the following definition placing it among other WE (World English) and ELT acronyms:

LSP (Language for Special/Specific Purposes): A language course designed to meet a predictable and specific range of communicative needs, such as scientists, doctors, lawyers, or air traffic controllers. (Crystal 2018, p. 114).

The prevalent applied perspective explicit in the definition is representative of activities in the field, but there is also a more tacit research-related element. The range of communicative needs that scientists, doctors, lawyers, air traffic controllers, and other professionals have must be first identified, analysed, and only finally included in relevant curricula. Thus, the definition shows the typical for LSP pairing of research and the application of its results. It is also worth noting that translation processes-learning how to express certain things in English as a foreign language-is presupposed in such contexts. 


\section{LSPs and other varieties}

Crystal (2018) lists a number of well-defined functional varieties of English, labelled as "occupational varieties", e.g. legal English, political English, religious and scientific English, and asserts that "[t]he term 'occupational dialect' has long been used for the distinctive language associated with a particular way of earning a living" (Crystal 2018, p. 394). Interestingly, it is claimed that occupational varieties are distinct from geographical and social origin-oriented varieties in that their features are "in temporary use"; they are 'part of the job' and used 'on the job' with no, or little class distinctions or related social features.

It is further claimed that all occupations are linguistically distinctive to some degree, although some of them are more distinct than others. Thus, it is relatively easy to characterise, e.g. religious English, which is "consciously retrospective" (Crystal 2018, p. 395) and prescriptive, but to a varied degree can also be imaginative and exploratory as there are different levels of expected creativity in different ritual patterns of behaviour across different religious practices.

The archaic dimension found in religious discourses can also be found in numerous legal contexts (cf., e.g. Witczak-Plisiecka, this volume and references within). In turn, medical and general scientific discourses rely even more on their "terms of art", key words that reflect the higher level of precision and expert typologies. In contrast, political discourse is marked by its focus on persuasion, argumentation, and the fact that it is public and "on record" (cf. Fetzer \& WitczakPlisiecka, 2021/in press). On the other hand, political disputes are not normally taken "at face value", but as moves in much more elaborate actions, and analysing their language requires insight into context that goes well beyond the "visible" situation. There are further less frequently described varieties, such as headlinese (the language of headlines), airspeak (including the language of air traffic controllers) and the language of dentistry, etc. (cf., e.g., Estival et al. 2016, Crosthwaite \& Cheung 2019), or discourses used in particular contexts (cf. Witczak-Plisiecka 2010), e.g. patient-doctor consultations.

There is much variety in LSPs and different patterns of description are needed. Typically, LSPs are characterised on a lexical, syntactic, and general stylistic level. Naturally, for different LSPs, different patterns of description will be relevant. As has been mentioned, scientific language, together with its medical variety relies on the lexical features more than, e.g. academic discourse, which will show more characteristic features on the stylistic level. The language of food recipes typically has characteristic syntactic form, and the language of politics shows regular patterns related to indirectness and suggested meaning, e.g. passages carrying linguistic presupposition, implicature, and stylistic features, such as 'the rule of three' (three-fold repetitions on a lexical, phrasal, or clausal 
lavel), metaphorical (often argumentative) imagery. It is often useful to discuss LSP adopting a genre-based approach.

An interesting and relatively new category in professional discourse is that of a "community of practice", a notion that also originated in the context of education as a social theory of learning. Initially, "communities of practice" denoted actual communities, groups of people who worked together, e.g. as tailors in Liberia or insurance company employees (cf. Lave \& Wenger 1991, Wenger 1998). The focus was on communication within such communities and the differences that such communication showed when compared to interaction with outsiders or novices. In theory a community of practice is a social network linked by: 1) mutual engagement; 2) a certain jointly negotiated enterprise; and finally 3) a shared repertoire. It is believed that within a network of that kind a new kind of "language", i.e. "a shared repertoire" emerges. This is triggered by the three characteristics which translate into coming to regular direct contact, while pursuing a common goal at the workplace. The community of practice approach is instrumental in showing the relative stability of functional varieties that emerge in professional contexts, and a reliance on their power on the part of discourse participants.

\section{LSPs and translation}

Holljen (2006), for instance, points out the importance of having practicing translators as teachers at higher education institutions, especially in the context of teaching LSP translation, and "the fast growing need for competent translators in a multilingual industrial world" (Holljen 2006, p. 42). It is stressed that the training involves "educating" students to be translators rather than "teaching" them translation.

Translating in an LSP contexts requires specific knowledge, and a special kind of competence. Communicative competence as defined in the European Union educational context involves: a) linguistic competence; 2) sociolinguistic competence; 3) discourse competence; 4) strategic competence; 5) sociocultural competence; and 6) social competence, and is directly linked with the development of social responsibility (cf. van Eck, 2001). Within this frame, linguistic competence embraces the words and structures of the language to be mastered, socio-linguistic competence is related to a correct choice of specific language forms and comes close to what is commonly referred to as pragmatic competence. Discourse competence focuses on the ability to use strategies in the construction and interpretation of texts that are appropriate in context and can be related to different genres and text formats. Strategic competence singles out damage-control patterns on behaviour in linguistic performance, whose application is usually much easier in one's native language in comparison to performance in foreign languages. Socio-cultural competence embraces, inter alia, 
empathy and a positive attitude towards experience. Finally, social competence is about the will and the skill to interact with others.

As of 2004, Belcher identified three main overlapping directions in which LSP pedagogy was developing, viz. sociodiscoursal, sociocultural, and socio-political, which to a certain degree reflect similar conceptualizations. The sociodiscoursal approach is focused on ESP connected with situated genre analysis understood after Hyland (2003, cf. also Swales 1990) as structured communicative events, which could be analysed with the use of corpus methodology. The sociocultural approach attracts attention to the relationship of from and relevant "rhetorical situations", the latter of which may be identified with a particular genre. The sociocultural approach converges with the above-mentioned research focused on the communities of practice (Lave \& Wenger 1991), and the "immersion" of learners in situated contexts where they can acquire practice. The socio-political approach foregrounds the necessity of a critical pedagogical perspective and attention paid to the distribution of power which is connected with the language forms used. Such problems need to be recognised both in the context of teaching English as a foreign language "at large", i.e. with no focus on translation, and in contexts where translation is seen as central.

Evidently, in the context of specialised communication, multidimensional competence must be emphasised as producing adequate translation involves not only substantial knowledge of the languages in question, but also expertise in the relevant LSP context, and often both recognition and application of societyoriented patterns of behaviour. A similar approach is posed by Nord (e.g. 1991), who emphasises the importance of the translator's insight into the details of the communicative event of which a translated text might be a part. It is stressed that contextual, extratextual information can be as crucial as adequate knowledge of both the source and the target language. As a result, in a wider perspective, building adequate theoretical models is necessarily specialised, if such models are to pay attention to the particularities of the specific domain, or embrace LSPs cross-linguistically and in their entirety.

\section{LSPs and translation in Research in Language 18(3)}

The papers gathered in the present volume all belong to the wide spectrum of LSP, and, with some variation, involve the problems of equivalence, even if they do not address translation proper directly.

The issue opens with Courtney G. Parkins-Ferrón's text "Are Translators Really Subservient? Empirical Evidence from Lexical Transfer and Language Prestige In Curaçao", which focuses on a fairly general perspective exploring the role ascribed to translators. This sociolinguistic study looks at issues of subservience from the perspective of agency in the English-to-Papiamentu lexical transfer process and at the influence of language prestige. Although the text does 
not address LSPs issues, it demonstrates the difference between professional translators and non-translators in their perception of lexical transfer, and the role that "agency" may have in such issues.

In "A few remarks on legal translation and intercultural encounters", Iwona Witczak-Plisiecka emphasises the difference between the legal culture and the lay culture, which may affect the process of translation performed in multiple legal context. The texts points to the convergence of translation-related processes found in legal discourses on both intralingual and interlingual levels, crosscutting the division between the source and the target language. It is claimed that numerous relations found between participants of law-related communication, are indeed relations of intercultural type, and potentially import problems naturally found in the context of intercultural communication.

Larisa Ilinska and Oksana Ivanova, practising LSP translators, present comments on the "Creation and Extension of Meaning in Professional Communication", focusing on the language of economy and showing the richness of metaphorical extensions found in scientific discourse. As the authors suggest, adopting a cognitive pragmatic approach allows to demonstrate how creative thinking and imagination are responsible for innovative, insightful linguistic imagery in professional communication and the language of science.

In a much different perspective, Małgorzata Z. Król offers comments "On the normative paradigm of sworn translation in the realm of law". The text emphasises the role that sworn translators play in society together with their both legal and social status as defined by the Polish Professional Sworn Translator's Code of 2018. The discussion exposes the requirements and expectations connected with sworn translation, which come close to those posed for lawyers, in that way making sworn translation even more special. The text also comments on some myths concerning linguistic meaning, legal meaning and semantic explicitness and literalness. It is demonstrated that faithfulness of translation in a legal context is a complex issue and legal interpretation, guided by uncodified legal paremias, can opt for the application of different criteria, e.g. interpretative vs. clarificative concept of interpreting the law. Such strategies are further enriched with formal levels of legal interpretation, viz. linguistic, systemic, and functional (teleological). Eventually, it is claimed that legal translation is special and specific as there is a fundamental difference between legal translation and other types of LSP-oriented translation practices, e.g. medical or scientific.

A rather different dimension is explored in "Metadiscourse in Academic Written and Spoken English: A Comparative Corpus-based Inquiry" by Mehrdad Vasheghani Farahani, which in a methodological perspective illustrates the use of corpora in the LSP field. Finally, "Colorative challenges in English economic terminology", authored by Tatiana S. Rosyanova, with the use of cognitive approach, discusses metaphorical colour-related linguistic imagery in the field of economy. 
The limited collection of papers included in Research in Language (2020), Vol. 18, Issue 3, can serve to illustrate the complexity of the field found in the interface of translation and LSP research with its richness of data and varied methodological approaches. Although the collection is not focused on one theme, there can be felt some gravity towards the problems of equivalence and "specific" meaning, backed with a need to provide their systematic account. As in other LSP and translation contexts, ESP and translation practices motivate theoretical investigations, while theoretical research results can inform relevant practices; the practical is interwoven with the theoretical.

\section{Conclusions}

Both LSP research and translation-related research emerged in an applied environment, but over the years both have grown and opened to theoretical investigations. It does not seem realistic that there may be one ideal theory explaining how translation and LSPs function, unless phrased in an extremely general way, but definitely there is ample space for "specialised" (sic!) theoretical models focused on particular domains, practices, and genres. Evidently, Hutchinson and Waters' (1987, p. 8) already classic approach phrased as: "Tell me what you need English for and I will tell you the English that you need" has not lost its relevance, and not just in the pedagogical context.

It is crucial that LSPs, together with translation processes performed and discussed in their contexts, should not be perceived as purely "lexical". It is only natural that LSPs are analysed with focus on their lexical, structural, and stylistic level, and that there are clear differences in which of the three levels is, or are, most "specific" for the variety in question. To provide an example, legal discourse of any (sub)kind is likely to show specific characteristics on all three levels, the language of recipes is more about lexis and structure, while medical discourse will probably exhaust the lexical stratum. However, consideration of the formal dimension is not enough, extratextual, less visible, features can often be of prime importance. Research in the field clearly shows that sensitivity to sociopragmatic and cultural issues is indispensable if proper understanding of LSP discourses is to be achieved both on the intralingual and the interlinguistic plane, especially in today's context of English as a lingua franca.

\section{References}

Bhatia, Vijay K. 1983. Analysing Genre: Language Use in Professional Settings. London: Longman. Belcher, Diane D. 2004. "Trends in Teaching English for Specific Purposes". Annual Revie of Applied Linguistics. Vol. 24, pp. 165-186. DOI: 10.1017/S026719050400008X

Crosthwaite, Peter \& Lisa Cheung. 2019. Learning the Language of Dentistry. Amsterdam/Philadelphia: John Benjamins. 
Crystal, David. 2018. The Cambridge Encyclopedia of the English Language. Cambridge: Cambridge University Press. https://doi.org/10.1017/9781108528931

Day, Jeremy \& Mark Krzanowski. 2011. Teaching English for Specific Purposes: An Introduction. Cambridge: Cambridge University Press.

Estival, Dominique, Canfance Farris and Brett Molesworth. 2016. Aviation English: A lingua franca for pilots and air traffic controllers. Abingdon: Routledge. https://doi.org/10.4324/9781315661179

Faber, Pamela \& Melania Cabezas-Garcia. 2019. "Specialized Knowledge Representation: from Terms to Frames". Research in Language, Vol. 17, No.2, pp. 197-211. https://doi.org/10.18778/1731-7533.17.2.06

Fetzer, Anita \& Iwona Witczak-Plisiecka. 2021 (in press). "Argumentative, Political and Legal Discourse". In: The Cambridge Handbook of Sociopragmatics, ed. by M. Haugh, D. Kádár \& M. Terkourafi. Cambridge: Cambridge University Press, pp. 520-543. https://doi.org/10.1017/9781108954105.027

Gollin-Kies, Sandra, David R, Hall \& Stephen H. Moore. 2015. Language for Specific Purposes. Houndmills, Basingstoke: Palgrave Macmillan. https://doi.org/10.1057/9781137500762

Holljen, Maj-Britt. 2006. "Practice Orientation in the Teaching of LSP Translation: A report on a practice-oriented project at the Centre for Translation Studies at Agder College, Kristiansand, Norway." Babel, Vol. 46, No. 1, pp. 41-46. https://doi.org/10.1075/babel.46.1.04hol

Hyland, K. (2003). Genre-based pedagogies: A social response to process. Journal of Second Language Writing, Vol. 12, pp. 17-29. https://doi.org/10.1016/S1060-3743(02)00124-8

Humbley, John, Gerhard Budin and Christer Laurén. 2018. Languages for Special Purposes: An International Handbook. deGruyter Mouton. https://doi.org/10.1515/9783110228014

Hutchinson, Tom \& Alan Waters. 1987. English for Specific Purposes. Cambridge: CUP. https://doi.org/10.1017/CBO9780511733031

Johns, Ann. 2013. "The history of English for Specific Purposes research". In Paltridge, B. \& S. Starfield (eds.), The Handbook of English for Specific Purposes. Chichester, UK: WileyBlackwell, 5-30. https://doi.org/10.1002/9781118339855.ch1

Lave, Jean \& Etienne Wenger. 1991. Situated Learning: Legitimate Peripheral Participation. Cambridge: Cambridge University Press. https://doi.org/10.1017/CBO9780511815355

Nord, Christiane. 1997. Translating as a Purposeful Activity, Manchester: St. Jerome.

Orr, Thomas. 2002. "The nature of English for specific purposes". In: English for Specific Purposes, ed. by T. Orr. Alexandria: TESOL (Teachers of English to Speakers of Other Languages), pp. 1-3.

Paltridge, Brian \& Sue Starfield (eds.). 2013. The Handbook of English for Specific Purposes. Chichester, UK: Wiley-Blackwell. https://doi.org/10.1002/9781118339855

Starfield (eds.), The Handbook of English for Specific Purposes. Chichester, UK: Wiley-Blackwell, 5-30.

Swales, J. (1990). Genre analysis: English in academic and research settings. New York: Cambridge University Press.

van Eck, Jan A. 2000 [1986]. Objectives for Foreign Language Learning, Vol. 1: Scope. Strasbourg: Council of Europe. http://docshare04.docshare.tips/files/25602/256022990.pdf (September 2019)

Wenger, Etienne. 1998. Communities of Practice: Learning, Meaning and Identity. Cambridge: Cambridge University Press. https://doi.org/10.1017/CBO9780511803932

Williams, Christopher. 2014. "The future of ESP studies: building on success, exploring new paths, avoiding pitfalls". Asp la revue de GERAS. Vol. 66: Intersection - l'anglais de spécialité, creuset multidomaine, pp. 137-150. Online since 01 November 2015, connection on 02 November 2020. URL : http://journals.openedition.org/asp/4616; DOI:

https://doi.org/10.4000/asp.4616 (accessed February 2019) 
Witczak-Plisiecka, Iwona. (ed.). 2010. Pragmatic Perspectives on Language and Linguistics, Vol.II:

Pragmatics of Semantically-Restricted Domains. Newcastle upon Tyne: Cambridge Scholars Publishing.

Woodrow, Lindy. 2018. Introducing Course Design in English for Specific Purposes. London \& New York: Routledge. https://doi.org/10.4324/9781315143279

\section{LSP journals sites}

Comparative Legilinguistics; https://pressto.amu.edu.pl/index.php/cl

English for Specific Purposes; https://www.journals.elsevier.com/english-for-specific-purposes

Ibérica; http://www.aelfe.org/?s=presentacio

Journal of Applied Linguistics and Professional Practice; https://journal.equinoxpub.com/JALPP

Journal of English for Academic Purposes; https://www.journals.elsevier.com/journal-of-englishfor-academic-purposes

The International Journal of Law, Language and Discourse; https://www.ijlld.com/

The Journal of Medical English Education;

https://mol.medicalonline.jp/en/archive/select?jo=cl9meden

LSP Journal-Language for special purposes, professional communication, knowledge management and cognition; https://rauli.cbs.dk/index.php/lspcog 